\title{
Effect of Media pH on Shoot Proliferation of Papaya (Carica papaya L.)
}

\author{
Neeharika Kanth*, Anil K. Singh and M.M. Syamal \\ Department of Horticulture, Institute of Agricultural Sciences, Banaras Hindu University, \\ Varanasi-221 005, (U.P.), India \\ *Corresponding author
}

\section{A B S T R A C T}

\section{Keywords}

$\mathrm{pH}$, shoot tip, Axillary bud, Shoot proliferation, Culture response.

Article Info

Accepted:

14 September 2017

Available Online:

10 October 2017
An experiment was conducted to study the effect of media $\mathrm{pH}$ on shoot proliferation of papaya using shoot tip and axillary bud as explant. The experiment was conducted in Completely Randomized Design with ten treatments and three replications. The aim of the experiment was to study the effect of media sucrose concentration on shoot proliferation while using shoot tip and axillary bud as explant. The different parameters taken for study were number of shoots per explant, length of shoot $(\mathrm{cm})$ and culture response (\%). The data stated that increasing the $\mathrm{pH}$ had a positive effect on these parameters upto some extent, but when $\mathrm{pH}$ was increased from 5.7, the different parameters showed a decreasing trend. The most suitable $\mathrm{pH}$ for shoot proliferation can be registered to be 5.7 .

\section{Introduction}

Papaya is an important fruit crop of tropical and subtropical regions of the world. It is regarded as the "wonder fruit" of tropics and subtropics. It is a fruit of high nutritive value and commercial significance. Scientifically, it is named Carica papaya L. Papaya belongs to family Caricaceae which includes 35 species, placed in six genera (Ming et al., 2007). Commercially, Carica papaya is the most important species in the genus Carica, being cultivated widely for consumption as fresh fruit and for use in drinks, jam, jellies, icecreams, pies and as dried and crystallized fruit. It is highly popular crop because of its high demand as a multi-purpose fruit, not only as dessert fruits but also as a source for chemical compounds for medicinal use like papain, chymopapain and carpaine. Even though grafting and budding techniques have been successful, they are not commercially practised, since the number of plants produced per mother plant is limited.

Thus, the use of micro propagation techniques, which can be used to produce a large number of true to type high quality planting material is an essential requirement in papaya cultivation. Furthermore, tissue culture techniques can be used as an important tool in crop improvement programmes since they help to overcome the problems experienced in conventional 
breeding methods and in rapid clonal production of crops (Farzana et al., 2008).

Clonal propagation through in vitro methods of known sex types is a better option since conventional techniques like use of cuttings and grafting have resulted in limited success. Papaya, being polygamous, requires that the explants be excised from a known sex type, which can be realised only when the tree attains reproductive maturity. Thus sex determination in papaya plants at the seedling stage or selecting explants from the mature tree enables propagation of the known sex. Successful true-to-type propagation under in vitro conditions can be achieved if explants are taken from seedlings (Patil et al., 2007).

Plant cells and tissues require an optimum hydrogen ion concentration $(\mathrm{pH})$ for the growth and development in cultures. The $\mathrm{pH}$ affects nutrient uptake as well as enzymatic and hormonal activities in plants (Bhatia and Ashwath, 2005). The $\mathrm{pH}$ of the culture medium is an important factor for proliferating shoots in-vitro. In the absence of $\mathrm{pH}$ regulation, the ionization of acidic and basic groups causes considerable changes in structure that affect their function at the cellular level (Karim et al., 2007). The $\mathrm{pH}$ level plays an effective role in enzyme and growth regulator activities that affect the function of cells as well as whole plants. $\mathrm{pH}$ of the medium also affects nutrients uptake and shoot proliferation. So, study was conducted to figure out the effect of different levels of media $\mathrm{pH}$ on shoot proliferation.

\section{Materials and Methods}

The experiment was conducted in Tissue culture laboratory, Department of Horticulture, Institute of Agricultural Sciences, Banaras Hindu University, Varanasi (U.P.), India. Murashige and Skoog media (Murashige and Skoog, 1962) was taken as basal media for all studies. The four stock solutions each of Macronutrients, micronutrients, Fe-EDTA and vitamins were prepared in advance. For preparing stock solutions I, II, III and IV appropriate amount of each chemicals were taken in volumetric flasks after dissolving them separately in a beaker with double distilled water and then the final volume was made up by adding double distilled water. Stock III was prepared by weighing $\mathrm{FeSO}_{4} .7 \mathrm{H}_{2} \mathrm{O}$ and sodium salt of EDTA. $2 \mathrm{H}_{2} \mathrm{O}$ separately in the required quantities, dissolved by slight warming, and then mixed thoroughly, $\mathrm{pH}$ was adjusted to 5.5. MS media was prepared by taking required amount of each of these stock solutions and final volume was made up to 1 litre by double distilled water. The different levels of $\mathrm{pH}$ of media was made by adjusting with either $0.1 \mathrm{~N} \mathrm{HCl}$ or $0.1 \mathrm{~N} \mathrm{NaOH}$. The different parameters studied were number of shoots per explant, length of shoot $(\mathrm{cm})$ and culture response $(\%)$. The number of shoots per plant were counted at different growth stages of plant in each treatment and was recorded. The length of proliferated shoots were measured in $(\mathrm{cm})$ and average was worked out for each explant. The culture response on sprouting of buds from explants in each treatment was recorded by dividing total number of cultures responding for sprouting and total number of cultures inoculated and calculated in percentage. The experiment was conducted in Completely Randomised Design (Panse and Sukhatme, 1967).

\section{Results and Discussion}

Table 1 depicts the data recorded with effect of different levels of $\mathrm{pH}$ of media with shoot tip as explant on number of shoots per explant and length of shoot $(\mathrm{cm})$ and culture response (\%). The data were statistically analysed and the interpretation of data are as follows. The data of effect of different levels of $\mathrm{pH}$ of 
media on number of shoots produced show that all the treatments gave a significant effect on number of shoots produced. Maximum number of shoots (10.83) was produced at $\mathrm{pH}$ 5.7 which was found statistically at par with $\mathrm{pH}$ 6.0. Minimum number of shoots per explant (0.00) was produced with $\mathrm{pH}$ 8.5. All the treatments exerted a significant effect on shoot length produced by the effect of different $\mathrm{pH}$. Maximum shoot length (4.50 $\mathrm{cm}$ ) was observed in case of $\mathrm{pH} 5.7$ which was significantly at par with $\mathrm{pH}$ 6.0. Minimum shoot length $(0.00 \mathrm{~cm})$ was noticed in $\mathrm{pH}$ 8.5. All the treatments caused significant effect on culture response.

Maximum culture response $(92.80 \%)$ was seen in $\mathrm{pH} 5.7$ which was statistically at par with $\mathrm{pH}$ 6.0. While, minimum $(0.00 \%)$ was seen in $\mathrm{pH} 8.5$.

Table.1 Effect of $\mathrm{pH}$ on shoot proliferation of papaya using shoot tip explant

\begin{tabular}{|l|l|l|l|l|}
\hline Treatments & $\mathbf{p H}$ & $\begin{array}{l}\text { Number of shoots } \\
\text { per explant }\end{array}$ & $\begin{array}{l}\text { Length of shoot } \\
(\mathbf{c m})\end{array}$ & $\begin{array}{l}\text { Culture } \\
\text { response (\%) }\end{array}$ \\
\hline $\mathrm{T}_{1}$ & 4.5 & 3.33 & 1.52 & 51.10 \\
\hline $\mathrm{T}_{2}$ & 5.0 & 2.66 & 1.03 & 45.08 \\
\hline $\mathrm{T}_{3}$ & 5.5 & 8.33 & 3.51 & 85.79 \\
\hline $\mathrm{T}_{4}$ & 5.7 & 10.83 & 4.59 & 92.80 \\
\hline $\mathrm{T}_{5}$ & 6.0 & 9.33 & 4.09 & 90.30 \\
\hline $\mathrm{T}_{6}$ & 6.5 & 8.16 & 3.72 & 80.52 \\
\hline $\mathrm{T}_{7}$ & 7.0 & 7.33 & 3.53 & 79.50 \\
\hline $\mathrm{T}_{8}$ & 7.5 & 3.00 & 1.43 & 48.33 \\
\hline $\mathrm{T}_{9}$ & 8.0 & 1.50 & 1.08 & 20.33 \\
\hline $\mathrm{T}_{10}$ & 8.5 & 0.00 & 0.00 & 0.00 \\
\hline SEm \pm & & 0.60 & 0.07 & 1.06 \\
\cline { 1 - 1 } C.D. at 5\% & & 1.79 & 0.21 & 3.13 \\
\hline
\end{tabular}

Table.2 Effect of $\mathrm{pH}$ on shoot proliferation of papaya using axillary bud explant

\begin{tabular}{|l|l|l|l|l|}
\hline Treatments & $\mathbf{p H}$ & $\begin{array}{l}\text { Number of shoots } \\
\text { per explant }\end{array}$ & $\begin{array}{l}\text { Length of shoot } \\
(\mathbf{c m})\end{array}$ & $\begin{array}{l}\text { Culture } \\
\text { response (\%) }\end{array}$ \\
\hline $\mathrm{T}_{1}$ & 4.5 & 2.33 & 1.24 & 46.33 \\
\hline $\mathrm{T}_{2}$ & 5.0 & 1.66 & 0.97 & 37.60 \\
\hline $\mathrm{T}_{3}$ & 5.5 & 7.66 & 3.26 & 79.16 \\
\hline $\mathrm{T}_{4}$ & 5.7 & 9.20 & 4.24 & 83.20 \\
\hline $\mathrm{T}_{5}$ & 6.0 & 8.16 & 3.55 & 81.50 \\
\hline $\mathrm{T}_{6}$ & 6.5 & 7.60 & 3.66 & 72.36 \\
\hline $\mathrm{T}_{7}$ & 7.0 & 6.33 & 2.59 & 66.53 \\
\hline $\mathrm{T}_{8}$ & 7.5 & 2.16 & 1.28 & 34.56 \\
\hline $\mathrm{T}_{9}$ & 8.0 & 1.16 & 1.05 & 19.50 \\
\hline $\mathrm{T}_{10}$ & 8.5 & 0.00 & 0.00 & 0.00 \\
\hline SEm \pm & \multirow{2}{*}{} & 0.67 & 0.03 & 1.02 \\
\cline { 3 - 5 } C.D. at 5\% & 2.00 & 0.10 & 3.02 \\
\hline
\end{tabular}


When axillary bud was taken as explant, as depicted in Table 2, all the treatments gave a significant effect on number of shoots produced. Maximum number of shoots (9.20) was found in $\mathrm{pH} 5.7$ which was statistically at par with $\mathrm{pH}$ 6.0. Minimum number of shoots per explant (0.00) was produced in case of $\mathrm{pH}$ 8.5. All the treatments exerted a significant effect on shoot length produced by the effect of different $\mathrm{pH}$. Maximum shoot length (4.24 $\mathrm{cm}$ ) was observed in case of $\mathrm{pH} 5.7$ which was significantly at par with $\mathrm{pH}$ 6.5. Minimum shoot length $(0.00 \mathrm{~cm})$ was noticed in $\mathrm{pH}$ 8.5. All the treatments caused significant effect on culture response. Maximum culture response $(83.20 \%)$ was seen in $\mathrm{pH} 5.7$ which was statistically at par with $\mathrm{pH}$ 6.0. While, minimum $(0.00 \%)$ was seen in $\mathrm{pH} 8.5$ and followed by $\mathrm{pH}$ 8.0.

The above results corroborate the findings of Patel et al., (2013), Faisal et al., (2006), Singh et al., (2008), Mumo et al., (2013).

It was observed that all the parameters namely, number of shoots per explant, length of shoot and culture response showed an increasing trend with the increase in $\mathrm{pH}$. But, as the $\mathrm{pH}$ was increased from 5.7 and above, decline in the trend of all the parameters were observed, irrespective of the type of explants used. Optimum $\mathrm{pH}$ for plant tissue culture has been described as 5.8+0.2 (Singh et al., 2008; Mumo et al., 2013; Patel et al., 2013; Ambasta and Kumari, 2013). The optimal pH level regulates the cytoplasmic activity that affects cell division and the growth of shoots and it does not interrupt the function of the cell membrane and the buffered $\mathrm{pH}$ of the cytoplasm. The $\mathrm{pH}$ also influences the status of the solidifying agent in medium, a $\mathrm{pH}$ higher than 6 produces a very hard medium and a $\mathrm{pH}$ lower than 5 does not sufficiently hard medium (Bhatia and Ashwath, 2005). The reduced $\mathrm{pH}$ might favor the assimilation of ions by the cultured cells from the medium and in turn regulation of metabolic pathway of cultured cells (Naik et al., 2010). From above studies, it can be concluded that MS basal media at $\mathrm{pH}$ was found most optimum for shoot proliferation in papaya.

\section{Abbreviations used}

$\mathrm{pH}$ : potential of Hydrogen ion, MS: Murashige and Skoog, EDTA: Ethylene diaminetetra acetic acid

\section{References}

Ambasta, S.K., and Kumari, S. 2013.Efficient procedure for clonal propagation of Carica papaya L. via shoot tip explants. I. J. Pl. Sci., 2 (1): 24-33.

Bhatia, P., and Ashwath, N. 2005. Effect of medium $\mathrm{pH}$ on shoot regeneration from the cotyledonary explants of tomato. Biotech, 4 (1): 7-10.

Faisal, M., Siddique, I. and Anis, M. 2006. Invitro rapid regeneration of plantlets from nodal explants of Mucuna pruriens - a valuable medicinal plant. Ann. Appl. Biol., 148: 1-6.

Farzana, A.R.F., Palkadapala1, P.G.V.N., Meddegoda1, K.M.M.N., Samarajeewa, P.K. and Eeswara1, J.P. 2008. Somatic embryogenesis in papaya (Carica papaya L. cv. Rathna) J. Natnl. Sci. Found., 36(1): 41-50.

Karim, M.Z., Yokota, S., Rahman, M.M., Eizawa, J., Saito, Y., Azad, M.A.K., Ishiguri, F., Iizuka, K. and Yoshizawa, N. 2007. Effect of the sucrose concentration and $\mathrm{pH}$ level on shoot regeneration from callus in Araria elata Seem. Asian of Pl. Sci., 6(4):715-717.

Ming, R.Q., Yu and Moore, P.H. 2007. Sex determination in papaya. Semin. Cell and Devlopmtl. Bio, 18: 401-408.

Mumo, N.N., Rimberia, F.K., Mamati, G.E., and Kihurani, A.W. 2013. In-vitro regeneration of selected Kenyan papaya 
(Carica papaya L.) lines through shoot tip culture. African J. Biotech., 12(49): 6826-6832.

Murashige, T., and Skoog, F. 1962. A revised medium for rapid growth and bio assays with tobacco tissue cultures. Physiol. Plantarum, 15: 473-497.

Naik, P.M., Manohar, S.H., Praveen, N. and Murthy, H.N. 2010.Effects of sucrose and $\mathrm{pH}$ levels on in-vitro shoot regeneration from leaf explants of Bacopa monnieri and accumulation of bacoside A in regenerated shoots. Plant Cell, Tissue and Organ Cul, 100:235239.

Panse, V. G., and Sukhatme, P.V. 1967.Statistical methods for agricultural workers. Indian Council of Agricultural Research, New Delhi, India.

Patel, J. R., Patel, R. M. and Patel, S. R. 2013. Factors affecting in-vitro establishment and growth of papaya (Carica papaya L.) var. Red Lady. Agres - An Internatl. E-J., 2(3): 332-341.

Patil, P., Vastrad, N., Dinesh, M. R. and Bantwal, A. R. 2007. A revised protocol for in-vitro propagation of Carica papaya using lateral buds from fieldgrown trees. J. Hort. Sci., 2(2): 99-103.

Singh, R., Yadav, R.C. and Yadav, N.R. 2008. In-vitro regeneration from mature female papaya plant cv. Selection 1 . Natnl. J. Pl. Improv., 10(1): 1- 4.

\section{How to cite this article:}

Neeharika Kanth, Anil K. Singh and Syamal, M.M. 2017. Effect of Media pH on Shoot Proliferation of Papaya (Carica papaya L.). Int.J.Curr.Microbiol.App.Sci. 6(10): 1633-1637. doi: https://doi.org/10.20546/ijcmas.2017.610.196 